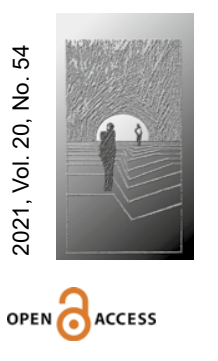

Katarzyna Nosek-Kozłowska

http://orcid.org/0000-0001-6435-1545

Uniwersytet Warmińsko-Mazurski

katarzyna.nosek@onet.eu

DOI: $10.35765 / \mathrm{hw} .2024$

\title{
Familial and Societal Situation of Both Only Children and Their Families in the Age of Pandemic. Selected Issues
}

\section{SUMMARY}

RESEARCH OBJECTIVE: The predominant goal of this article is to put emphasis on issues only children face in the modern world. The theoretical scope of the paper incorporates the specificity of the only child phenomenon, the familial situation of only children, as well as the possibility of maintaining social contacts and developing in the current pandemic-driven situation.

THE RESEARCH PROBLEM AND METHODS: Research problems have the form of the following questions: What is the familial situation of children not having any siblings? How does the pandemic affect the upbringing of only children? What conditions for development and opportunities for establishing social contacts does the age of pandemic create for only children? The analytical and synthetic method of the literature approach to the subject has been applied.

THE PROCESS OF ARGUMENTATION: Basing on scientific studies, the specificity of the only child phenomenon has been identified, most important features of the family-oriented educational environment have been distinguished, as well as the nature of functioning of a family having a single child only has been elaborated on.

RESEARCH RESULTS: Consideration on the issues raised within the scope of this paper has indicated that the only child's interactions with adults should have an appropriate form and nature. It is necessary to keep a healthy balance between the world of children and the world of adults.

CONCLUSIONS, INNOVATIONS, AND RECOMMENDATIONS: It has been noticed that the modern perception of only children is changing, which is the result of expanding interpersonal relations and the development of technology. Contemporary only children do not remain in absolute isolation from the environment.

$\rightarrow$ KEYWORDS: FAMILY, ONLY CHILDREN, UPBRINGING, PANDEMIC 


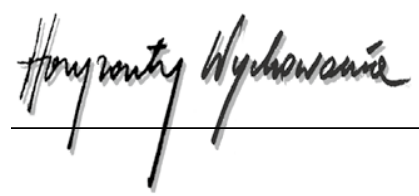

\section{STRESZCZENIE}

Sytuacja rodzinna i społeczna jedynaków i ich rodzin w dobie pandemii. Wybrane zagadnienia

CEL NAUKOWY: Celem artykułu jest zaprezentowanie problemu jedynactwa we współczesnym świecie. Teoretyczny namysł obejmuje charakterystykę merytoryczną problemu jedynactwa, sytuacji rodzinnej jedynaków oraz możliwości utrzymywania przez nich kontaktów społecznych i ich rozwoju w aktualnej sytuacji pandemii.

PROBLEM I METODY BADAWCZE: Problematyka została ujęta w postaci następujących pytań: Jak wygląda sytuacja rodzinna dzieci nieposiadających rodzeństwa? W jaki sposób pandemia wpływa na wychowanie dzieci jedynych? Jakie warunki rozwoju i możliwości nawiązywania kontaktów społecznych stwarza jedynakom funkcjonowanie w dobie pandemii? Zastosowano metodę analityczno-syntetyczną literatury przedmiotu.

PROCES WYWODU: Na podstawie opracowań naukowych dokonano charakterystyki jedynactwa, wskazano najważniejsze cechy środowiska wychowawczego rodziny, a także ukazano specyfikę funkcjonowania rodzin z jednym dzieckiem. Punktem wyjścia do podjętych analiz są wyniki badań empirycznych dotyczące problematyki jedynactwa.

WYNIKI ANALIZY NAUKOWEJ: Refleksja nad podjętą problematyką wskazuje na fakt, że kontakty jedynaka $z$ dorosłymi powinny mieć odpowiednią formę i treść. Konieczne jest zachowanie dystansu między światem dzieci a światem dorosłych. Nadmierne jego zmniejszanie grozi jedynakom znacznie bardziej w sytuacji pandemicznej niż dzieciom posiadającym rodzeństwo.

WNIOSKI, INNOWACJE, REKOMENDACJE: Dostrzeżono, że współczesny obraz jedynactwa ulega zmianie, co jest efektem rozszerzających się stosunków międzyludzkich czy też rozwoju techniki. Współcześni jedynacy nie pozostają w bezwzględnej izolacji od otoczenia, mimo trudnej sytuacji panującej na świecie.

\section{$\rightarrow$ SŁOWA KLUCZOWE: RODZINA, JEDYNACTWO, WYCHOWANIE, PANDEMIA}

\section{Introductory remarks}

A family is undoubtedly the most common educational environment for human beings. It influences the behavior of an individual, his or her attitude towards other people, as well as towards values, norms, and patterns of behavior (Wojciechowska-Charlak, 2005). A properly formed family is characterized by the presence of educational values that cannot be replaced by other environments. M. Sobecki also points out that a family is the societal unit where one can identify one's deep cultural roots for the very first time. It depends on the strength of its cultural capital, as well as on the intensity and quality of interactions within it (Sobecki, 2016). The closest family is of the greatest importance 
when it comes to building identity, because it is the unit in which strongest interactions and initial identifications are developed (Sobecki, 2016).

In pedagogics-oriented literature of the subject, there is a rather remarkable lack of studies on issues related to the upbringing and functioning, both familial and social, of children having no siblings. The phenomenon in question is of a notable importance in modern times. The number of families with many children is decreasing, whereas the model based on small and even single-child families is becoming more and more fashionable.

Both twentieth and twenty-first centuries are undoubtedly the time of demographic changes affecting, inter alia, the quantitative structure of the family. Z. Dąbrowska-Caban (1999) and K. Slany (2000) indicate that Poland is following the path of changes connected with the so-called second demographics, which was influenced by postmodern changes, characterized mainly by technological and socio-economic changes in the society leading to the modification of systems of values and beliefs (Slany, 2000.). A statement issued by the CPOR basing on a piece of research entitled "Procreation needs and both the preferred and implemented family models" has shown that almost all Polish citizens declared that they wanted to have children. Only four percent of respondents said they would prefer not to have kids. Nevertheless, every tenth Polish citizen would like to have only one child. While compared to 1996, there is a slight change in Polish people's declarations regarding the desired number of children. Today, slightly more individuals claim that they do not want to have children at all, but it is still a rather negligible group. Invariably, the largest number of people express the willingness to have two children, whereas some others would like to have three. The number of individuals who would like to have four or more children has slightly decreased over time (Komunikat CBOS, 2012).

We are dealing with a kind of "revolution" in the sphere of marital and family life (Komunikat CBOS, 2012). In addition, in 2020, an infectious disease of the respiratory system caused by the SARS-CoV-2 virus started spreading all over the world, namely COVID-19. It resulted in the implementation of the state of pandemic in many countries around the world, thus affecting the functioning of people being members of society and the functioning of families. The pandemic also has also been affecting the process of upbringing, especially in the case of children without siblings. Said problem may be considered to be an interesting issue requiring in-depth empirical analyzes.

\section{Only children as perceived by the literature of the subject}

Single children can be perceived as a multidimensional societal phenomenon. Only children are defined as children living in normal, properly functioning families, and having no siblings (Winnicott, 1993, p. 134). In the majority of cases, there are justifiable reasons for such a state of affairs and most often having only one child is caused by economic conditions. Being the only child in a given family has its pros and cons. The parents' 


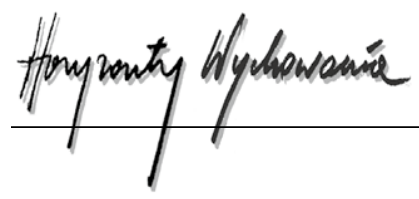

attention is focused on a single child, satisfying all his or her needs, and ensuring best conditions for his or her development. On the other hand, such a child may lack a playmate at home and may not have experiences resulting from contacts with younger and older siblings (Winnicott, 1993, p. 135). Having fun with an adult is not the same kind of entertainment as playing with a child, as the latter is typically accompanied by recklessness, impulsiveness, and inconsistency in action. Due to constant contact with adults, the only children may become excessively mature and prefer to be accompanied by adults, rather than by children.

Over the years, various, often contradictory opinions about only children have been formulated. Some of them stated that only children are more intelligent, more interested by the world surrounding them, able to behave properly, and more adequately adapted to future life than their peers from large families. Other opinions state that only children are less interested in their environment and less adapted to the changing reality (Rembows$\mathrm{ki}, 1975)$. Therefore, the question is: What is an only child? According to J. Zborowski (1975) "the term only child is related to the concept of the one and only child in a given family." The author focuses in his concept on a child who is a classic only child. Nevertheless, one can also discuss a certain category of children whose situation is similar to the one of a family with one child. Said phenomenon is referred to as the "apparent only child" and is identified in large families. It may refer to, for example, a boy raised among girls, or vice versa. A position similar to an only child may also be assigned to the youngest child in a large family (Bochniarz, 2010).

The oldest known research conducted on only children was carried out in 1891 by E. Kolrausche. He proved that only children may have a different personality, motivations, and patterns of behavior than children from large families (Campbell, 1934). The research in question presented only children as self-possessed, selfish, and haughty (as cited in Rembowski, 1975). An examination on the psychological characteristics of only children, conducted by P. Połomski (2002), did not show any significant differences between the studied group of only children and children having siblings in terms of social functioning. In both groups, it was considered to be normal. The few revealed differences in said respect were within the acceptable, average level. By showing positive features of the only children in the family, a positive image of a child without siblings started to emerge. According to Ronald W. and Lois A. Richardson, only children show high life-related expectations, because they receive more from their parents - in both psychological and material sense - than their peers from large families. Children who are well taken care of by their parents and who receive a lot of attention tend to be successful in school, but may have problems with relationships with peers, because they are often too mature for their age (Richardson \& Richardson, 2001). H. Cudak (2004), who examined the process of socialization of only children and those having siblings, pointed to some differences with regard to their socialization. Only children achieved the same or a similar level of development of pro-social behavior as a result of shaping and developing cognitive processes, as well as due to some preconditions responsible for forming their personality traits. The dynamics of the progress of said processes 
should certainly be explained by pointing to the greater number and frequency of social contacts of only children with adults (Cudak, 2004).

Today, only children are no longer perceived negatively. The familial situation of an only child includes a myriad of positive features properly governing the development of his or her personality. Any deficiencies can be compensated for through contacts with a wider social circle. Gradually more often, the benefits of being an only child are pointed out.

\section{Families including only children and chosen aspects of their functioning}

A family is considered by experts who are well-versed in pedagogy as an institution of natural education, being separate from peer groups and the local community. As such, it has to carry out certain educational tasks allowing it to achieve specific results in the course of performing various activities. Each type of human activity may have an educational impact on children, adolescents, and adults, even if its goals are different than education. Such type of parenting is often called unreflective, unintentional or indirect education. In every social environment, there is always a strictly educational activity. Then, one may discuss reflective, intentional, and planned education, especially when it involves a mental effort and conscious activity of educators, striving to implement the assigned educational tasks. The aforementioned two types of education always exist and complement each other. In the family, there is undoubtedly the predominance of natural education, but there are also elements of intentional, planned and purposeful education to be identified (Kawula at al., 2014).

Family-based education can be considered to be a broad process involving various activities, both within the family and outside it, performed in order to stimulate the development of personality of family members, as well as to prepare them for social life. The process of upbringing in a family is a series of education-related changes experienced by family members, constituting subjective components of natural or deliberately organized upbringing situations, connected in an interaction-based manner and allowing to achieve both basic and more advanced upbringing-related goals, which in turn directly affect changes in the psyche, personality, sense of identity, and behavioral patterns of family members, being either educators or pupils (Cudak, 2004, p. 108).

To sum up, it has to be stated that contemporary knowledge on educational environments, including a family, is diverse. Nevertheless, issues with researching them are still present and become gradually more complex (Cichosz, 2014b). There are new sociodemographic, political and health problems identifiable on a global scale that influence the functioning of modern families. For over a year, the whole world has been facing the crisis caused by the covid-19 pandemic. Said virus has not only caused an economic disaster, but has also disrupted relationships and made it impossible for a number of families to perform their care-related and educational tasks. Initially, people were isolated 


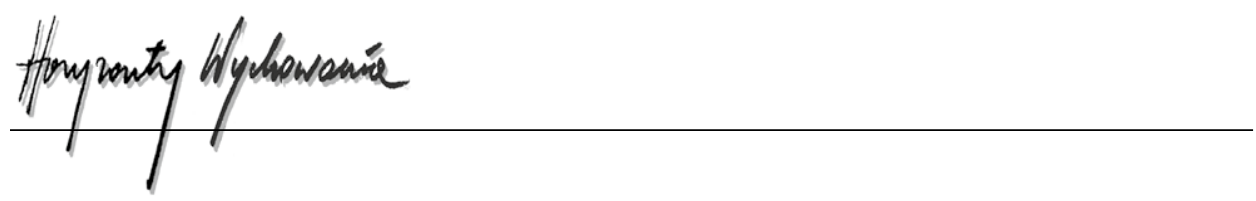

in their own homes and surrounded by their immediate family. They could devote time to rebuilding family relationships, which could have been disturbed by either workload or daily duties. Many families took advantage of said moment very effectively, but in the case of many others - some problems were identified, often caused by the inability to cope with a crisis situation, affecting not only large families, but also those including one child.

For many families, the pandemic has become the cause of a crisis, including the social, health, material, or a familial one. A crisis is then perceived as losing control of life while at the same time having no remedial options, namely - strategies or both internal and external (societal and environmental) resources (Nowak, 2012). It is possible that many families have experienced the phenomenon of losing control over their own lives, which could have been caused by the adoption of restrictions related to the pandemic, transfer of school-related and professional responsibilities from traditional to online ones, loss of job, or the inability to provide for the family.

The situation of Polish children during the pandemic has been shown in an online research report by Urszula Markowska-Manista and Dominika Zakrzewska-Olędzka (2020). This pandemic situation we have to deal with particularly affects, as the authors have pointed out, children who - for their own safety and the safety of their families (mainly grandparents) - have been disallowed to participate in activities and events being a part of an established routine of their everyday lives. Due to the epidemic, most families have introduced new rules of functioning, after prior consulting them with their children. The most common rules have related to: frequent hand washing and paying special attention to hygiene, limitations with regard to external contacts and leaving home, remote learning caused by the closure of schools and kindergartens, as well as the reorganization of daily routine. The authors have emphasized that:

The results of the study carried out indicated various problems that families faced in everyday life at the turn of March and April 2020. The situation of children and their parents, who were (without any warning) forbidden to engage in their daily routines and locked in houses for several weeks, was something completely new to the majority of them. Despite the widespread access to the mass media, information-oriented chaos could be observed, causing a sense of public uncertainty about both the current situation and ways of dealing with it. The presented pieces of information were mainly addressed to adults, ignoring both the needs and perspective of children and adolescents. Neither politicians nor journalists allowed children and young adults to ask questions, which should be answered with respect and empathy by adults responsible for ensuring the social and mental safety of the youngest members of the society. The temporary lockdown connected with a number of restrictions of civil rights caused social and professional activities of families to take place in the virtual world, in which family members have been trying to find a new rhythm of everyday life (Markowska-Manista \& Zakrzewska-Olędzka, 2020, pp. 18-20).

On the basis of the discussed piece of research, it can be concluded that the needs of children and adolescents that are connected with their functioning in various walks of life have often been ignored during the pandemic. Being locked in homes with their 
parents and subjected to an online learning system has taken away the opportunity for children to meet the need of establishing factual social contacts with their peers, as well as with their grandparents, who are an invaluable support in the process of creating intergenerational bonds. The very fact of being locked in a house/apartment could be perceived by the youngest members of the society as a threat to their sense of security, being strictly connected with depriving them of the possibility of carrying out daily activities or limiting wide possibilities of physical development that are available while functioning normally. The online learning process has also been a new and sometimes difficult experience for children and adolescents.

The pandemic has also limited social contacts of only children, which were largely based on relations with their parents. What effect has it had on such children? What educational conditions has it created?

Upbringing conditions depend not only on the composition of the family and are not only limited to being an only child. They are determined by a number of other factors, such as the specificity and nature of adults taking care of such a child - especially when it comes to parents, their attitude towards the child, and general approach. Enabling an only child to establish wider social contacts may have a positive effect on his or her intellectual development. Such an opportunity is offered by, for example, allowing such a child to attend a nursery, kindergarten, school, stay in a day-room, or participate in extracurricular activities. Nevertheless, we have been living in a world that limits our social contacts to a large extent. Children have been locked in homes with adults for the period of quarantine. Some of them still learn in a remote manner and are therefore deprived of natural, spontaneous contacts with their peers. In the light of current events, the situation of children not having siblings seems to be much worse than the one of children having siblings.

Nevertheless, the overall nature of a child brought up without siblings depends on factors being inherent in a given family, among which the most important are parental attitudes, the main part of which are approach to children, i.e. specific patterns of behavior, the scope and frequency of contacts between the child and his or her peers, parents' personality traits, and their relation with such child (Bochniarz, 2010).

There are families in which parents limit contacts with their only child to a minimum, as well as are very preoccupied with their professional work and the matters surrounding them. There are also families in which parents devote as much time as possible to their children. Thanks to numerous interactions with adults, such children learn more about the world around them and develop quickly in intellectual terms. It sometimes happens that such children begin to show interest in fields that are not typical of their peers, but are common to adults. The accelerated development of only child's interests and the change in their quality resulting from frequent contact with adults may be a positive phenomenon, but may also have a negative impact on such an individual (Filipczuk, 1976). Said child will probably have more difficulties establishing contacts with peers and will not be able to find a common ground with them. This, in turn, may lead to loneliness or the desire to dominate others, which will result in serious conflicts with peers. The only 


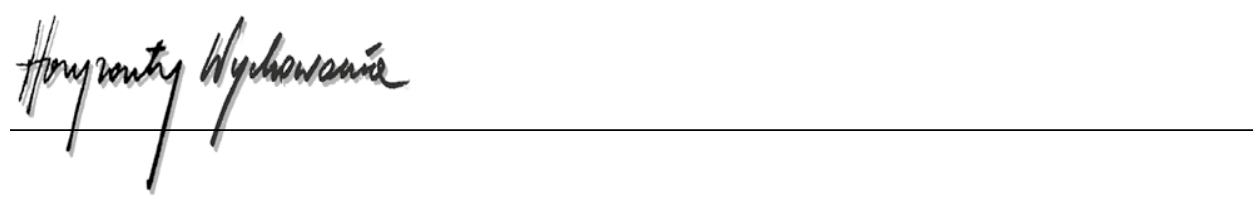

child in the family is the main point of focus, which causes the parents to care for him or her much more than required. They show him or her uncritical love, without opting for any punishments in the event of wrongdoing, which strengthens the belief of his or her privileged position and may lead to egoistic attitudes in life (Turowska, 1987). Only child's contacts with adults should be of appropriate form and nature. It is necessary to keep the world of children and the world of adults apart. Mixing them threatens only children much more than children having siblings in the era of the pandemic. Jagieła (2006) presented the most typical psychological features of people who grew up without siblings, including:

a) Feeling of loneliness

It is not understood as a kind of abandonment, but rather - as a feeling of separateness and alienation, isolation from other people. It is not loneliness perceived literally, but rather the willingness to protect one's own privacy

b) Strong bonds with parents

Only children feel very responsible for their parents and their well-being. In situations of conflict between the parents, they often act as mediators. It may be stated that their personal satisfaction with life is related to the happiness of their parents. The degree of child's socialization depends on many factors, including the care taken of the child at home, as well as in nurseries, kindergartens, and in schools. A child spends several hours a day in a group of peers there. Friendships are formed there, coexistence and cooperation patterns are formed, and the child's personality develops. It seems that said process is still going on, despite the ongoing pandemic. After the period of home isolation, children, especially the youngest ones, can return to stationary institutions nurseries, kindergartens, and schools. Older children, thanks to the level of technological development our society has achieved, meet virtually, but still have the opportunity of maintaining contact with their peers and making friends. They learn to function in the contemporary reality that has changed remarkably over the last year.

\section{Closing remarks}

In families, "the number of children is decreasing at an alarming pace. Children also experience a completely new form of deprivation and poverty: they are pampered with all the items in the world, but they often get gradually poorer when it comes to interpersonal contacts" (Beer, 2005). It would seem that the current situation would additionally contribute to the impoverishment of the sphere of children's social contacts. It can be stated, however that direct contacts have been suspended for a certain period, but children meet on a daily basis - if not in real life, then at last in a virtual space.

Only children are more or less acutely affected by various types of pressure. They have to bear a heavy burden of responsibility, expectations, and guilt as they have had 
to serve several roles for their parents. They often experience difficulties in adjusting their image to who they really are and experience the sense of loneliness (Pitkeathley \& Emerson, 2007). Therefore, it becomes important to shape the educational culture of the society, mainly of parents and potential candidates for parents, in order to popularize parenting activities aimed at the development of children's societal capabilities. First of all, parents must devote a lot of attention and time to the process of child socialization. Children having siblings have daily opportunities to improve their social competences. Only children also have the opportunity to do so, however, as they can practice with their peers, younger and older children from the immediate and distant family, as well as with young neighbors.

The pandemic related to the spread of the covid-19 virus has certainly significantly changed the familial situation of only children. Only children having no siblings have been locked in their homes with their parents and other adults. They have been deprived of factual contacts with their peers, the elderly, and the social environment. They have found themselves in a difficult and often incomprehensible situation. Direct contacts have been suspended for a certain period, but children have been meeting on a daily basis if not in real space, then in virtual one. They have also been maintaining relations with their grandparents thanks to various technological devices. They have create a kind of digital space in which they can maintain existing and build new relationships with members of family, peers, or social groups.

The contemporary image of an only child is changing, which is the result of expanding interpersonal relations and the development of technology.

\section{BIBLIOGRAPHY}

Beer, U. (2005). Rodzina - model z przyszłością. Jedynak - charakter i szanse (M. Dąbrówka \& M. Jatowska, Trans.). Warszawa: Wydawnictwo „BestPress”.

Bochniarz, A. (2010). Postawy rodzicielskie a funkcjonowanie społeczne jedynaków. Lublin: Wydawnictwo Uniwersytetu Marii Curie-Skłodowskiej.

Campbell, A. (1934). The personality adjustments of only children. The Psychological Bulletin, 3, 193-203.

Cichosz, M. (2014). Pedagogika społeczna. Zarys problematyki. Kraków: Oficyna Wydawnicza Impuls.

Cudak, H. (2004). Problemy uspołecznienia dzieci jedynych w rodzinie współczesnej. In Z. Tyszka (Ed.), Współczesne rodziny polskie - ich stan i kierunek przemian (pp. 84-118). Poznań: Wydawnictwo Naukowe UAM.

Dąbrowska-Caban, Z. (1999). Rodzina polska u progu XX wieku. Problemy Rodziny, 4, 23-29. Filipczuk, H. (1976). Kłopoty z jedynakami. Warszawa: Instytut Wydawniczy Nasza Księgarnia. Jagieła, J. (2006). Jedynak w szkole. Krótki poradnik psychologiczny. Kraków: Wydawnictwo Rubikon.

Kawula, S., Brągiel, J. \& Janke, A.W. (2014). Pedagogika rodziny: obszary i panorama problematyki. Toruń: Wydawnictwo Adam Marszałek.

Komunikat CBOS. (2012). Potrzeby prokreacyjne oraz preferowany i realizowany model rodziny. https://www.cbos.pl/SPISKOM.POL/2012/K_061_12.PDF 


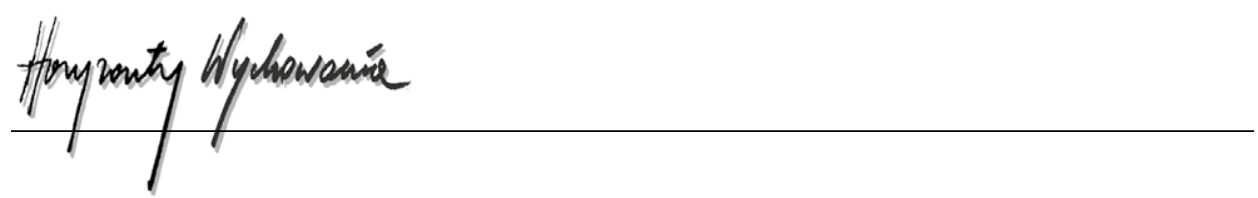

Markowska-Manista, U. \& Zakrzewska-Olędzka, D. (2020). Rodziny z dziećmi w nowej sytuacji epidemii koronawirusa. Raport z badań online. https://www.pskorczak.org.pl/strony/pliki_pdf/ raport_covid_19_2020r.pdf

Nowak, B.M. (2012). Rodzina w kryzysie. Studium resocjalizacyjne. Warszawa: Wydawnictwo Naukowe PWN.

Pitkeathley, J. \& Emerson, D. (2007). Jedynacy. Jak być (z) jedynakiem (I. Szyszkowska-Andruszko \& R. Waśkiewicz, Trans.). Warszawa: Jacek Santorski \& Co.

Połomski, P. (2002). Psychologiczna charakterystyka jedynaków. Polskie Forum Psychologiczne, 2(7), 160-173.

Radochoński, M. (1998). Wybrane zagadnienia psychopatologii w ujęciu systemowej koncepcji rodziny. Roczniki Socjologii Rodziny, 10, 91-109.

Rembowski, J. (1975). Jedynactwo dzieci w domu i w szkole. Wrocław: Zakład Narodowy im. Ossolińskich, Wydawnictwo Polskiej Akademii Nauk.

Richardson, R.W. \& Richardson, L.A. (2001). Najstarsze, średnie, najmłodsze. Jak kolejność narodzin wpływa na Twój charakter. Gdańsk: Gdańskie Wydawnictwo Psychologiczne.

Slany, K. (2000). Przemiany demograficzne w Polsce końca XX wieku. Problemy Rodziny, 4, 7-12.

Sobecki, M. (2016). Rodzinne uwarunkowania kształtowania tożsamości. Pedagogika Społeczna, 1(59), 125-136.

Turowska, L. (1987). Środowisko rodzinne jedynaka a jego przystosowanie szkolne. Wrocław: Zakład Narodowy im. Ossolińskich, Wydawnictwo Polskiej Akademii Nauk.

Winnicott, D.W. (1993). Dziecko, jego rodzina i świat (A. Bartosiewicz, Trans.). Warszawa: Jacek Santorski \& CO Agencja Wydawnicza.

Wojciechowska-Charlak, B. (2005). Rodzina jako środowisko wychowawcze. In T.E. Dąbrowska i B. Wojciechowska-Charlak. Między praktyką a teorią wychowania (pp. 197-204). Lublin: Wydawnictwo Uniwersytetu Marii Curie-Skłodowskiej.

Zborowski, J. (1975). Uczeń - jedynak. Warszawa: Wydawnictwa Szkolne i Pedagogiczne.

\section{Copyright and License}

This article is published under the terms of the Creative Commons Attribution - NoDerivs (CC BY- ND 4.0) License http://creativecommons.org/licenses/by-nd/4.0/ 